\title{
EFFECT OF DRYING-OFF PERIOD ON YIELD AND QUALITY OF SOME SUGARCANE VARIETIES
}

\author{
Abazied, Sakina R. ${ }^{(1)}$ and E.H.S. El-Laboudy ${ }^{(2)}$ \\ ${ }^{(1)}$ Technology, ${ }^{(2)}$ Agronomy Res. Dept., Sugar Crops Res. Inst., ARC, Giza, Egypt
}

\section{ABSTRACT}

The present work was carried out during 2018/2019 (plant cane) and 2019/2020 (first ratoon) at Kom Ombo Agricultural Research Station, (latitude of $24^{\circ} 28^{\prime}$ North and longitude of $32^{\circ} 57^{\prime}$ East at an elevation of 108 $\mathrm{m}$ above sea level), Aswan Governorate to find out the optimum drying-off period (15, 30, 45 and 60 days before harvesting date) for five sugarcane varieties (G.T.54-9, G.84-47, G.2003-47, G.99-103 and Cu.57-14). A randomized complete block design, in strip plot arrangement, with three replications, was used.

The results showed that the two studied factors affected significantly all studied traits in the virgin cane and its first ratoon crop. The highest values of sucrose, purity, richness, sugar recovery percentages and sugar yield/fad were recorded with 30 days drying-off, while the highest values of millable cane weight and cane yield were obtained, sugarcane was dried-off for 15 days. The promising variety G.2003-47 showed the superiority over the other varieties in sucrose, purity, richness, sugar recovery percentages, and sugar yield, while the highest values of millable cane weight and cane yield/fad were given by G.99-103.

Under the conditions of the current work, on Kom Ombo, sugarcane crop irrigation should be withheld for 30 days before harvesting for maximum sugar yield/fad.

\section{INTRODUCTION}

Sugar cane, as a robust tillering crop, requires adequate application of fertilizers, water, dense solar radiation and warmth to grow well. On the other hand, it requires a dry, cool period, associated with low soil moisture content, caused by withholding irrigation before harvesting for an appropriate period to enhance its ripening i.e., accelerate the translocation of sugar from leaves to the millable canes. On the contrary, prolonging fasting duration before harvesting may negatively affect cane quality and sugar yield. To determine the optimum duration of stopping irrigation before harvesting, many investigators studied the effect of dry-off period on yield and quality of sugarcane. Among them, Khaleifah (1990); Donaldson and Bezuidenhout (2000); Inman-Bamber and Smith (2005); Olivier, et al. (2006); Abiy and Negi (2014); Getaneh and Negi (2014); Hagos, et al. (2014); Abdelkarim, and Mahdi, (2015); Getaneh, et al. (2015); Araújo, et al. (2016) and Ashagre and Khan (2020).

It is known that sugarcane varieties are the corner stones to maximize productivity per unit area. Nowadays, the commercial variety G.T.54-9 
occupies most of the area planted with sugarcane in Egypt. Recently, Sugar Crops Research Institute released some new varieties of sugarcane, among them G.84-47, G.99-103 and G.2003-47. Many investigators reported differences among sugarcane varieties in growth, yield and quality traits as El-Geddawy, et. al. (2002); El-Shafai and Ismail (2006); Taha, et al. (2008); El-Maghraby, et al. (2009); Abazied, (2018); Gadallah and Mehareb (2020) and Ahmed, et al. (2020).

The objective of this study was to determine the optimum dry-off period for sugarcane fields in order to achieve the maximum sugar yield/fad.

\section{MATERALS AND METHODS}

The present work was carried out during 2018/2019 (plant cane) and 2019/2020 (first ratoon) at Kom Ombo Agricultural Research Station, (latitude of $24^{\circ} 28^{\prime}$ North and longitude of $32^{\circ} 57^{\prime}$ East at an elevation of 108 $\mathrm{m}$ above sea level), Aswan Governorate to find out the optimum drying-off period $(15,30,45$ and 60 days before harvesting) for five sugarcane varieties (G.T.54-9, G.84-47, G.2003-47, G.99-103 and Cu.57-14). A randomized complete block design, in strip plot arrangement, with three replications was used, where drying-off periods were located in the horizontal plots, while sugarcane varieties were randomly distributed in the vertical ones. Plot area was $35 \mathrm{~m}^{2}$, including five rows of one meter apart and seven meters in length. Sugarcane varieties were planted in the $1^{\text {st }}$ week of March and harvested at twelve-month age, in both seasons. Plots left without irrigation for $15,30,45$ and 60 days before harvesting. Some meteorological data for ten weeks (from1 January to 6 March, in 2019 and 2020) during withholding irrigation at Kom Ombo were recorded in Table (1). All plots received the other agricultural operations as recommended by the Sugar Crops Research Institute (SCRI).

Table (1): Meteorological data from $1^{\text {st }}$ January to $6^{\text {th }}$ March 2019 and 2020 at Kom Ombo

\begin{tabular}{|c|c|c|c|c|c|c|c|c|}
\hline \multirow{3}{*}{ Week } & \multicolumn{4}{|c|}{2019} & \multicolumn{4}{|c|}{2020} \\
\hline & \multicolumn{2}{|c|}{ Temperature $^{\circ} \mathrm{C}$} & \multicolumn{2}{|c|}{ Humidity \% } & \multicolumn{2}{|c|}{ Temperature $^{\circ} \mathrm{C}$} & \multicolumn{2}{|c|}{ Humidity \% } \\
\hline & Min & Max & Min & Max & Min & Max & Min & Max \\
\hline $1^{\text {st }}$ & 4.9 & 21.3 & 30.3 & 94.0 & 4.6 & 20.4 & 30.0 & 85.7 \\
\hline $2^{\text {nd }}$ & 3.6 & 20.4 & 27.4 & 100.1 & 2.2 & 18.4 & 32.0 & 90.1 \\
\hline $3^{\text {th }}$ & 3.7 & 24.0 & 29.7 & 106.6 & 6.5 & 24.1 & 24.9 & 96.7 \\
\hline $4^{\text {th }}$ & 3.0 & 26.9 & 22.0 & 92.4 & 5.6 & 20.1 & 31.6 & 83.4 \\
\hline $5^{\text {th }}$ & 7.3 & 24.9 & 24.9 & 82.6 & 5.8 & 23.3 & 22.3 & 89.9 \\
\hline $6^{\text {th }}$ & 10.7 & 27.8 & 28.1 & 65.6 & 5.5 & 25.3 & 24.9 & 88.7 \\
\hline $7^{\text {th }}$ & 5.9 & 23.7 & 28.4 & 89.4 & 6.5 & 23.0 & 32.7 & 81.9 \\
\hline $8^{\text {th }}$ & 5.2 & 23.9 & 24.7 & 87.0 & 7.8 & 25.7 & 30.9 & 86.0 \\
\hline $9^{\text {th }}$ & 10.2 & 26.3 & 26.7 & 73.3 & 7.4 & 25.0 & 30.8 & 89.1 \\
\hline $10^{\text {th }}$ & 6.7 & 26.1 & 23.6 & 75.1 & 8.4 & 29.7 & 22.6 & 80.0 \\
\hline
\end{tabular}

Source: Agricultural meteorological Station, Kom Ombo Sugar Factory, Aswan 


\section{The recorded data:}

At harvest, a sample of twenty millable canes was taken from each treatment to determine the following traits:

1. Millable cane weight/plant $(\mathrm{kg})$.

2. Sucrose \% was determined using a "Saccharimeter" as shown in A.O.A.C. (2005).

3. Juice purity $\%$ was calculated according to the equation of Singh and Singh (1998) as follows:

Juice purity $\%=$ sucrose $\%$ x $100 /$ TSS $\%$.

4. Richness \% was calculated according to the equation described by E.S.I.I.C. (1981).

Richness $\%=($ sucrose $\% \mathrm{~g}$ juice $\mathrm{x}$ richness factor $) / 100$

Where:

Sucrose $\%$, g juice $=\left(\right.$ sucrose $\% \mathrm{~cm}^{3}$ juice $) /$ juice density

Juice density was taken from Schibler's Tables.

Richness factor $=100$ - (fiber \% x 1.3).

5. Sugar recovery $\%$ was calculated according to the equation of Yadav and Sharma (1980) as follows:

Sugar recovery $\%=[\mathrm{S} \%-0.4(\mathrm{~B} \%-\mathrm{S} \%)] \times 0.73$

Where:

$\mathrm{S} \%$ : sucrose percentage and $\mathrm{B} \%=$ brix percentage

0.4 : each pound of non-sucrose solids in cane juice retains 0.4 pound of sucrose as outlined by Hebert (1973).

0.73: a correction factor for actual milling condition in factories that depends on the overall mean fiber\% cane during processing as outlined by Mathur (1997).

8. Cane yield/fad (ton) was calculated based on plot area.

9. Sugar yield/fad (ton) was calculated according to the following equation as described by Mathur (1997):

Sugar yield/fad (ton) $=$ cane yield/fad (ton) $\mathrm{x}$ sugar recovery $\%$.

Statistical analysis:

The collected data were statistically analyzed according to the method described by Snedecor and Cochran (1981). Treatment means were compared using LSD at 5\% level of difference as outlined by Steel and Torrie (1980).

\section{Millable cane weight:}

\section{RESULTS AND DISCUSSION}

Data in Table (2) showed that millable cane weight was significantly and gradually decreased as the drying-off period was prolonged up to 60 days in the two growing seasons. The reduction in millable cane weight could be attributed to moisture loss. These results are in harmony with those obtained by Donaldson and Bezuidenhout 
(2000) and Abiy and Negi (2014), who found significant differences in stalk weight with delaying drying-off period.

The results showed that the tested sugarcane varieties differed significantly in the single millable cane weight/plant. Sugarcane G.99103 variety exhibited the superiority in this growth trait, recording $(0.225$ and $0.199 \mathrm{~kg}),(0.397$ and $0.333 \mathrm{~kg}),(0.378$ and $0.330 \mathrm{~kg})$ and $(0.431$ and $0.341 \mathrm{~kg}$ ) over that given by G.T.54-9, G.84-47, G.2003-47 and C.57-14 cane varieties, in the plant cane and first ratoon, respectively. Meanwhile, it can be noticed that C.57-14 cane variety had the lightest single stalk among the evaluated varieties. These results may be attributed to the genetic differences among varieties. These results are in accordance with those obtained by El-Maghraby, et al. (2009); Abazied (2018) and Gadallah and Mehareb (2020), who found substantial variances among the tested sugarcane varieties in cane weight in both seasons.

Table (2): Effect of drying-off period on millable cane weight $(\mathrm{kg} / \mathrm{plant})$ of some sugarcane varieties in plant and first ratoon cane crops during 2018/2019 and 2019/2020

\begin{tabular}{|c|c|c|c|c|c|c|c|c|c|c|}
\hline \multirow{3}{*}{$\begin{array}{c}\text { Sugarcane } \\
\text { varieties }\end{array}$} & \multicolumn{5}{|c|}{ Plant cane crop } & \multicolumn{5}{|c|}{$1^{\text {st }}$ ratoon crop } \\
\hline & \multicolumn{4}{|c|}{ Drying-off period (day) } & \multirow{2}{*}{ Mean } & \multicolumn{4}{|c|}{ Drying-off period (day) } & \multirow{2}{*}{ Mean } \\
\hline & 15 & 30 & 45 & 60 & & 15 & 30 & 45 & 60 & \\
\hline G.T.54-9 & 1.342 & 1.356 & 1.299 & 1.240 & 1.309 & 1.212 & 1.208 & 1.177 & 1.134 & 1.183 \\
\hline G.84-47 & 1.167 & 1.164 & 1.135 & 1.083 & 1.137 & 1.071 & 1.070 & 1.045 & 1.010 & 1.049 \\
\hline G.2003-47 & 1.180 & 1.179 & 1.153 & 1.110 & 1.156 & 1.071 & 1.071 & 1.046 & 1.021 & 1.052 \\
\hline G.99-103 & 1.577 & 1.569 & 1.533 & 1.456 & 1.534 & 1.418 & 1.412 & 1.375 & 1.323 & 1.382 \\
\hline Cu. 57-14 & 1.131 & 1.128 & 1.100 & 1.051 & 1.103 & 1.063 & 1.061 & 1.035 & 1.005 & 1.041 \\
\hline Mean & 1.279 & 1.279 & 1.244 & 1.188 & & 1.167 & 1.164 & 1.136 & 1.099 & \\
\hline \multicolumn{11}{|c|}{ LSD.at 0.05 level for: } \\
\hline \multicolumn{5}{|c|}{ Drying-off periods (A) } & 0.003 & & & & & 0.002 \\
\hline \multicolumn{5}{|c|}{ Sugarcane varieties (B) } & 0.015 & & & & & 0.009 \\
\hline \multicolumn{5}{|c|}{$A \times B$} & 0.035 & & & & & 0.015 \\
\hline
\end{tabular}

Millable cane weight was appreciably influenced by the interaction between varieties and drying-off periods in both cane crops. In the plant cane, insignificant differences were detected in stalk weight of G.84-47, G.2003-47 and C.57-14, when irrigation was cut-off for 15 and up to 45 days before harvesting. However, fresh millable cane weight of G.T.54-9 and G.99-103 decreased substantially as the period of fasting was extended from 15 to 45 days after the last irrigation. These findings show that the period of irrigation cutting-off should not exceed 30 days before harvesting for G.T.54-9 and G.99-103 varieties.

\section{Sucrose percentage:}

The results in Table (3) indicate that sucrose\% in cane juice was significantly affected by drying off period. A gradual increase in sucrose $\%$ was recorded as the period of irrigation withholding before harvesting was prolonged up to 45 days, and decreased thereafter at 60 days, in both 
seasons. Meantime, insignificant variance was found among 30, 45 and 60 days of fasting before harvesting, in their influence on this quality trait, in the $1^{\text {st }}$ season, as well as between 45 and 60 days, in the $2^{\text {nd }}$ one. Moreover, the lowest sucrose\% was recorded in canes fastened for 15 days only, probably due to higher cane water content, negatively affect sucrose $\%$, determined as sucrose, $\mathrm{g}$ in $100 \mathrm{~cm}^{3}$ of cane juice, where the higher the water content in juice, the lower the sucrose $\%$, and vice versa. On the contrary, the results cleared that canes deprived of the water supply for longer period up to 45 days had higher sucrose $\%$. On the other hand, the exposure of canes to an extreme fasting up to 60 days before harvest, led to a reduction in sucrose \%, probably due to the conversion of stored sucrose (disaccharide) in canes, into glucose and fructose (mono-saccharides) to get energy under severe drought conditions. In fact, the reduction of moisture content in canes before harvest, caused by moderate drought conditions force canes to accumulate more sucrose in cane juice. These results are in agreement with those reported by Donaldson and Bezuidenhout (2000); Abiy and Negi (2014); Hagos, et al. (2014), Abdelkarim and Mahdi (2015) and Ashagre and Khan (2020), who noted an increase in sucrose percent as dry-off period was extended up to the 60 days.

Table (3): Effect of drying-off period on sucrose percentage of some sugarcane varieties in plant and first ratoon crops, during 2018/2019 and 2019/2020

\begin{tabular}{|c|c|c|c|c|c|c|c|c|c|c|}
\hline \multirow{3}{*}{$\begin{array}{c}\text { Sugarcane } \\
\text { Varieties }\end{array}$} & \multicolumn{5}{|c|}{ Plant cane crop } & \multicolumn{5}{|c|}{$1^{\text {st }}$ ratoon crop } \\
\hline & \multicolumn{4}{|c|}{ Drying-off period/day } & \multirow{2}{*}{ Mean } & \multicolumn{4}{|c|}{ Drying-off period/day } & \multirow{2}{*}{ Mean } \\
\hline & 15 & 30 & 45 & 60 & & 15 & 30 & 45 & 60 & \\
\hline G.T.54-9 & 16.12 & 16.84 & 17.00 & 17.04 & 16.75 & 16.52 & 17.30 & $\mathbf{1 7 . 5 0}$ & $\mathbf{1 7 . 5 6}$ & 17.22 \\
\hline G.84-47 & 16.37 & 16.96 & 17.41 & $\mathbf{1 7 . 3 5}$ & 17.02 & 16.80 & $\mathbf{1 7 . 5 8}$ & 18.21 & 18.10 & 17.67 \\
\hline G.2003-47 & 18.21 & 18.86 & 18.66 & 18.54 & 18.57 & 18.64 & 19.34 & 19.17 & 19.10 & 19.06 \\
\hline G.99-103 & 15.80 & 16.25 & 16.16 & 16.05 & 16.07 & 16.28 & 16.87 & 16.83 & 16.78 & 16.69 \\
\hline Cu. 57-14 & 16.68 & 17.10 & 17.14 & 17.17 & 17.02 & 17.07 & 17.39 & 17.95 & 18.01 & 17.68 \\
\hline Mean & 16.64 & $\mathbf{1 7 . 2 0}$ & 17.27 & 17.23 & & 17.06 & $\mathbf{1 7 . 7 6}$ & 17.93 & 17.91 & \\
\hline \multicolumn{11}{|c|}{ LSD at 0.05 level for: } \\
\hline \multirow{2}{*}{\multicolumn{5}{|c|}{$\begin{array}{l}\text { Drying-off periods (A) } \\
\text { Sugar cane yarieties (B) }\end{array}$}} & 0.18 & & & & & 0.09 \\
\hline \multirow{2}{*}{\multicolumn{5}{|c|}{$\begin{array}{l}\text { Sugar cane varieties (B) } \\
\text { A } \times \text { B }\end{array}$}} & 0.19 & & & & & 0.24 \\
\hline & & & & & 0.39 & & & & & 0.48 \\
\hline
\end{tabular}

The results indicated that the tested sugarcane varieties varied significantly in sucrose \% in the plant and first ratoon crops. Sugarcane G.2003-47 had a relative advantage in this trait over the other varieties, recording the highest value of sucrose $\%$, while the lowest one was given by G.99-103 variety, in in both seasons. Varietal differences may be attributed to their genetic make-up. These results are in agreement with those obtained by El-Shafai and Ismail (2006); Taha, et al. (2008) and 
Ahmed, et al. (2020), who found significant variance among the evaluated cane varieties in sucrose $\%$.

Sucrose\% responded significantly to the interactions among the two studied factors in both seasons. The tested sugarcane varieties did not behave the same under the four drying-off periods In the $1^{\text {st }}$ season, sucrose\% of G.84-47 variety was significantly increased by increasing drying-off period from 30 to 45 days. However, insignificant variance in this quality trait was recorded by the other varieties as exposed to these two fasting durations. Similarly, an appreciable increase in sucrose $\%$ of G.84-47 and C.57-14 was detected as the period of irrigation withholding was extended from 30 to 45 days before harvest, without significant difference in this quality characteristic of the other varieties as influenced by these two periods of fasting, in the $1^{\text {st }}$ ratoon cane crop.

\section{Juice purity percentage:}

Data in Table (4) showed that the juice purity percentage was affected significantly by drying-off period treatment in both seasons. Also, data displayed declining trend starting from 30 days, to reach its lowest value at 60 days after withholding irrigation, which could be attributed to the negative effect of drastic moisture stress on the photosynthetic rate and sucrose accumulation. Similar results were reported by Getaneh and Negi (2014); Hagos, et al. (2014) and Ashagre, and Khan (2020), who reported that withholding irrigation period significantly affected purity percentage. Insignificant difference between 15 and 45 days of fasting in their influence on juice purity $\%$, in the $1^{\text {st }}$ ratoon cane crop.

The results in Table (4) indicate that the evaluated cane varieties differed significantly in purity $\%$ in the plant cane and its first ratoon crops. In both seasons, G.2003-47 showed the superiority in juice purity\% over the other varieties, while G.99-103 variety recorded the lowest value of this trait. Moreover, insignificant variance in purity\% was found between G.T.54-9 and G.84-47 grown as plant cane crop. Likewise, G.T.54-9, G.84-47 and C.57-14 varieties did not differ significantly in this quality trait, in the $1^{\text {st }}$ ratoon cane crop. These results are probably referred to the same performance and tendency recorded by these varieties concerning sucrose\% (Table 3), where it is known that, the higher the sucrose $\%$ of cane juice, the higher the purity $\%$ and vice versa. The variation among sugarcane varieties in their juice purity\% was reported by El-Geddawy, et al. (2002); El-Shafai and Ismail (2006) and Gadallah and Mehareb (2020), who found significant difference among the evaluated sugarcane varieties in juice purity\%. 
Table (4): Effect of drying-off period on purity percentage of some sugar cane varieties in plant and first ratoon crops, during 2018/2019 and 2019/2020

\begin{tabular}{|c|c|c|c|c|c|c|c|c|c|c|}
\hline \multirow{3}{*}{$\begin{array}{c}\text { Sugarcane } \\
\text { Varieties }\end{array}$} & \multicolumn{5}{|c|}{ Plant cane crop } & \multicolumn{5}{|c|}{$1^{\text {st }}$ ratoon crop } \\
\hline & \multicolumn{4}{|c|}{ Drying-off periods/day } & \multirow[t]{2}{*}{ Mean } & \multicolumn{4}{|c|}{ Drying-off periods/day } & \multirow[t]{2}{*}{ Mean } \\
\hline & 15 & 30 & 45 & 60 & & 15 & 30 & 45 & 60 & \\
\hline G.T.54-9 & 85.29 & 87.25 & 86.34 & 80.57 & 84.86 & 85.60 & 87.59 & 86.45 & 81.11 & 85.19 \\
\hline G.84-47 & 85.44 & 86.97 & 84.84 & 81.38 & 84.66 & 86.38 & 87.29 & 85.36 & 82.27 & 85.33 \\
\hline G.2003-47 & 87.76 & 90.37 & 88.28 & 86.31 & 88.18 & 88.17 & 90.50 & 88.47 & 86.23 & 88.34 \\
\hline G.99-103 & 84.13 & 85.08 & 82.74 & 78.33 & 82.57 & 84.79 & 85.94 & 83.36 & 78.48 & 83.14 \\
\hline Cu. 57-14 & 85.94 & 86.32 & 83.81 & 80.95 & 84.26 & 87.00 & 88.16 & 84.29 & 81.42 & 85.22 \\
\hline Mean & 85.71 & 87.20 & 85.20 & 81.51 & & 86.39 & 87.90 & 85.59 & 81.90 & \\
\hline \multicolumn{11}{|c|}{ LSD at 0.05 level for: } \\
\hline \multicolumn{5}{|c|}{ Drying-off periods (A) } & 0.23 & & & & & 0.46 \\
\hline \multicolumn{5}{|c|}{ Sugar cane varieties (B) } & 0.30 & & & & & 0.49 \\
\hline \multicolumn{5}{|c|}{$A \times B$} & 0.59 & & & & & 0.99 \\
\hline
\end{tabular}

The results showed that purity\% was significantly responded to the interaction between the studied factors, in both seasons. In the plant cane, insignificant difference in juice purity\% of G.3003-47 was found, when fasting duration was prolonged from 30 to 45 days. The same finding was detected in the $1^{\text {st }}$ ratoon cane crop. However, juice purity\% of G.47-84 and G.99-103 varieties markedly decreased as affected by extending the irrigation cutting-off period from 30 to 45 days before harvesting, in both cane crops.

\section{Richness percentage:}

Data in Table (5) pointed out that drying-off period treatment significantly affected richness percentage (Pol \%) in the two seasons. The results displayed a declining trend in richness\% starting from 30 and 45 days after irrigation withholding, in the $1^{\text {st }}$ and $2^{\text {nd }}$ season, respectively, without significant variance between these two fasting periods in their influence on this trait, in both seasons. The increase in richness\% accompanied extending drying off period from 15 to 30 days was due to an increase in sucrose content (Table 3 ). In addition, excessive of fasting of canes for 60 days before cutting led to a substantial reduction in richness \% in comparison to that recorded at 45 days, in both seasons. These results are in agreement with those obtained by Khaleifah (1990); Getaneh, et al. (2015) and Ashagre and Khan (2020), who found that the recorded richness \% was significantly higher in canes fastened for 50 days than those deprived from irrigation supply for 60 days.

Data in the same table pointed to a significant difference among the evaluated sugar cane varieties in richness\%, in both seasons. The highest mean value of this trait was recorded by the promising sugarcane variety G.2003-47, while the lowest was recorded by G.99-103 variety. These results are probably attributed to the same trend exhibited by these two varieties in respect to sucrose\%, which is the main factor in richness \% estimation (Table 3). These results are in agreement with those 
reported by Abazied (2018) and Ahmed, et al. (2020), who found significant difference in richness\% among the tested sugarcane varieties.

Table (5) Effect of drying-off period on richness percentage of some sugar cane varieties in plant and first ratoon crops, during 2018/2019 and 2019/2020

\begin{tabular}{|c|c|c|c|c|c|c|c|c|c|c|}
\hline \multirow{3}{*}{$\begin{array}{c}\text { Sugarcane } \\
\text { Varieties }\end{array}$} & \multicolumn{5}{|c|}{ Plant cane crop } & \multicolumn{5}{|c|}{$1^{\text {st }}$ ratoon crop } \\
\hline & \multicolumn{4}{|c|}{ Drying-off periods/Day } & \multirow[t]{2}{*}{ Mean } & \multicolumn{4}{|c|}{ Drying-off periods/Day } & \multirow[t]{2}{*}{ Mean } \\
\hline & 15 & 30 & 45 & 60 & & 15 & 30 & 45 & 60 & \\
\hline G.T.54-9 & 13.34 & 13.87 & 13.92 & 13.76 & 13.72 & 13.59 & 14.15 & 14.27 & 14.07 & 14.02 \\
\hline G.84-47 & 13.51 & 13.94 & 14.15 & 13.95 & 13.89 & 13.75 & 14.33 & 14.67 & 14.42 & 14.29 \\
\hline G.2003-47 & 15.11 & 15.61 & 15.34 & 15.09 & 15.29 & 15.39 & 15.93 & 15.73 & 15.45 & 15.63 \\
\hline G.99-103 & 13.05 & 13.37 & 13.19 & 12.94 & 13.14 & 13.36 & 13.78 & 13.63 & 13.42 & 13.55 \\
\hline Cu. 57-14 & 13.82 & 14.14 & 14.10 & 13.88 & 13.99 & 14.06 & 14.54 & 14.61 & 14.80 & 14.50 \\
\hline Mean & 13.77 & 14.19 & 14.14 & 13.92 & & 13.03 & 14.55 & 14.58 & 14.43 & \\
\hline \multicolumn{11}{|c|}{ LSD at 0.05 level for: } \\
\hline \multicolumn{5}{|c|}{ Drying-off periods (A) } & \multicolumn{5}{|l|}{0.06} & 0.10 \\
\hline \multicolumn{5}{|c|}{ Sugar cane varieties (B) } & \multicolumn{5}{|l|}{0.08} & 0.11 \\
\hline \multicolumn{5}{|c|}{$A \times B$} & \multicolumn{5}{|l|}{0.17} & 0.22 \\
\hline
\end{tabular}

The interaction between varieties and drying-off periods significantly affected richness\%. In the plant cane, it was found that extending fasting period from 30 to 45 days had insignificant effect on richness \% recorded by G.T.54-9 and C.57-9, while richness\% of the other cane varieties was significantly reduced at 45 days. In the $1^{\text {st }}$ ratoon cane crop, richness\% of G.84-47 variety increased markedly with prolonging irrigation cutting-off period from 30 to 45 days, while the other cane varieties were insignificantly influenced.

\section{Sugar recovery percentage:}

Different drying-off periods had a significant effect on sugar recovery\% (Table 6). It was noticed that lengthening the period of irrigation withholding before harvesting from 15 to 30 days caused an appreciable increase in sugar recovery\%. Thereafter, a gradual reduction in this quality trait was recorded, in the plant and $1^{\text {st }}$ ratoon cane crops. Meantime, insignificant variance was found in sugar recovery\% in cases exposed to 30 or 45 days of fasting. These results manifest that sugar canes should be subjected to a moderate drought to slow down their vegetative growth and enhance sugar translocation and storage in canes, raising sugar recovery\%. Similar results were reported by Oliver, et al. (2006); Hagos, et al. (2014) and Abdelkarim and Mahdi (2015), who found that percentage of recoverable sucrose was significantly affected by drying-off period.

The results in the same table pointed to a significant variation among the studied cane varieties in sugar recovery\%. The results pointed out that G.2003-47 variety characterized with the best value of this trait, while G.99-103 variety occupied the last rank among the tested varieties, in both seasons, probably due to the same performance of varieties, concerning sucrose\% (Table 3). It can be noticed that the variances 
among G.T.54-9, G.84-47 and C.57-14 varieties were insignificant in the plant cane crop. These results coincide with those mentioned by ElGeddawy, et al. (2002); El-Shafai and Ismail (2006) and Ahmed, et al. (2020), who mentioned that sugarcane varieties differed significantly in sugar recovery\%.

Table (6) Effect of drying-off period on sugar recovery percentage of some sugarcane varieties in plant and first ratoon crops, during 2018/2019 and 2019/2020

\begin{tabular}{|c|c|c|c|c|c|c|c|c|c|c|}
\hline \multirow{3}{*}{$\begin{array}{c}\text { Sugarcane } \\
\text { Varieties }\end{array}$} & \multicolumn{5}{|c|}{ Plant cane crop } & \multicolumn{5}{|c|}{$1^{\text {st }}$ ratoon crop } \\
\hline & \multicolumn{4}{|c|}{ Drying-off periods/day } & \multirow[t]{2}{*}{ Mean } & \multicolumn{4}{|c|}{ Drying-off periods/day } & \multirow[t]{2}{*}{ Mean } \\
\hline & 15 & 30 & 45 & 60 & & 15 & 30 & 45 & 60 & \\
\hline G.T.54-9 & 10.96 & 11.57 & 11.62 & 11.24 & 11.35 & 11.25 & 11.91 & 12.01 & 11.62 & 11.70 \\
\hline G.84-47 & 11.14 & 11.64 & 11.80 & 11.51 & 11.52 & 11.49 & 12.09 & 12.33 & 12.07 & 12.00 \\
\hline G.2003-47 & 12.55 & 13.18 & 12.89 & 12.68 & 12.83 & 12.88 & 13.53 & 13.28 & 13.05 & 13.19 \\
\hline G.99-103 & 10.66 & 11.05 & 10.81 & 10.42 & 10.74 & 11.03 & 11.51 & 11.30 & 10.91 & 11.19 \\
\hline Cu. 57-14 & 11.38 & 11.69 & 11.55 & 11.35 & 11.49 & 11.72 & 12.17 & 11.92 & 11.77 & 11.90 \\
\hline Mean & 11.34 & 11.83 & 11.73 & 11.44 & & 11.67 & 12.24 & 12.17 & 11.88 & \\
\hline \multicolumn{11}{|c|}{ LSD at 0.05 level for: } \\
\hline \multicolumn{5}{|c|}{ Drying-off periods (A) } & \multicolumn{5}{|l|}{0.21} & 0.13 \\
\hline \multicolumn{5}{|c|}{ Sugar cane varieties (B) } & \multicolumn{5}{|l|}{0.18} & 0.18 \\
\hline \multicolumn{5}{|c|}{$A \times B$} & \multicolumn{5}{|l|}{0.34} & 0.35 \\
\hline
\end{tabular}

The interaction between the two studied factors had a significant effect on sugar recovery\% in both seasons. In the plant cane, it was noticed that difference in sugar recovery\% of G.T.54-9, G.84-47 and G.3003-47 varieties was substantially improved, when irrigation prohibition period was prolonged from 15 to 45 days. Nevertheless, each of G.99-103 and C.57-14 varieties recorded almost the same values of this trait, without significant variance in case they were fastened for 15 or 45 days. The same results were obtained in the $1^{\text {st }}$ ratoon.

6. Cane yield/fad:

Data in Table (7) indicate that drying-off periods had a significant effect on cane yield/fed in the plant and its first ratoon cane crops. Practicing drying-off periods of 15, 30, 45 and 60 days before harvesting was accompanied a decrease of $0.162,1.397$ and 3.618 ton of canes/fad, successively, in the plant cane crop, corresponding to $0.316,1.493$ and $3.671 \mathrm{ton} / \mathrm{fad}$, in the first ratoon crop. These results may be referred to the reduction of the single millble cane weight/plant (Table 2) as the of irrigation withholding was increased. Moreover, insignificant variance in cane yield/fad was noticed, when irrigation was stopped for 15 and/or 30 days before harvesting, in both cane crops. These results are in agreement with those reported by Khaleifah, (1990); Donaldson and Bezuidenhout (2000); Inman-Bamber (2002); Olivier, et al. (2006) and Hagos, et al. (2014), who found that cane yield was significantly influenced by drying off period. 
The results pointed to significant differences among the tested varieties with respect to cane yield/fad in the two seasons. Sugar cane G.99103 variety out-yielding G.T.54-9, G.84-47, G.2003-47 and C.57-14 varieties by $2.715,6.984,7.197$ and $8.901 \mathrm{ton} / \mathrm{fad}$, in the plant cane crop, respectively, corresponding to $3.478,5.162,7.408$ and 7.504 ton/fad, in the $1^{\text {st }}$ ratoon. The superiority of G.99-103 was actually due to its greatest millable cane weight (Table 2). These findings are in line with those found by Taha, et al. (2008); El-Maghraby, et al. (2009); Abazied (2018) and Ahmed, et al. (2020), found that there were recorded significant differences among the tested varieties in cane yield.

Table (7): Effect of drying-off period on cane yield/fad (ton) of some sugarcane varieties in the plant and first ratoon cane crops, during 2018/2019 and 2019/2020

\begin{tabular}{|c|c|c|c|c|c|c|c|c|c|c|}
\hline \multirow{3}{*}{$\begin{array}{c}\text { Sugarcane } \\
\text { Varieties }\end{array}$} & \multicolumn{5}{|c|}{ Plant cane crop } & \multicolumn{5}{|c|}{$1^{\text {st }}$ ratoon crop } \\
\hline & \multicolumn{4}{|c|}{ Drying-off periods/day } & \multirow[t]{2}{*}{ Mean } & \multicolumn{4}{|c|}{ Drying-off periods/day } & \multirow[t]{2}{*}{ Mean } \\
\hline & 15 & 30 & 45 & 60 & & 15 & 30 & 45 & 60 & \\
\hline G.T.54-9 & $\mathbf{5 3 . 5 3 4}$ & 53.294 & 51.844 & 49.497 & 52.042 & 49.392 & 49.202 & 47.932 & 46.203 & 48.182 \\
\hline G.84-47 & 49.020 & 48.895 & 47.685 & 45.491 & 47.773 & 48.209 & 47.170 & 46.070 & 44.544 & 46.498 \\
\hline G.2003-47 & 48.560 & 48.542 & 47.457 & 45.682 & $\mathbf{4 7 . 5 6 0}$ & 45.884 & 45.873 & 44.830 & 40.421 & 44.252 \\
\hline G.99-103 & 56.313 & 56.003 & 54.730 & 51.983 & 54.757 & 53.013 & 52.783 & 51.383 & 49.462 & 51.660 \\
\hline Cu. 57-14 & 47.034 & 46.917 & 45.757 & 43.717 & 45.856 & 45.100 & 44.990 & 43.920 & 42.614 & 44.156 \\
\hline Mean & 50.892 & 50.730 & 49.495 & 47.274 & & 48.320 & 48.004 & 46.827 & 44.649 & \\
\hline \multicolumn{11}{|c|}{ LSD at 0.05 level for: } \\
\hline \multicolumn{5}{|c|}{ Drying-off periods (A) } & \multicolumn{5}{|l|}{0.909} & 1.262 \\
\hline \multicolumn{5}{|c|}{ Sugar cane varieties $(B)$} & \multicolumn{5}{|l|}{0.775} & 1.149 \\
\hline \multicolumn{5}{|c|}{$A \times B$} & \multicolumn{5}{|l|}{1.550} & 2.298 \\
\hline
\end{tabular}

The interaction between drying-off period and sugarcane varieties significantly affected cane yield/fad, in both seasons. Cane yield was significantly affected by the interaction between drying-off period and varieties in both seasons. Significant reduction in cane yield given by G.T.54-9 and G.99-103 varieties was recorded in case of extending fasting duration from 15 to 45 days. However, these two periods of irrigation withholding had insignificant influence on cane yield of the other tested varieties, in the plant cane crop. This means that the varieties did not behave the same at the different drying-off period. Generally, highest cane yield was recorded with the promising variety G. 99-103 with 15 days drying-off in both seasons.

\section{Sugar yield/fad:}

The results in Table (8) showed that sugar yield was substantially influenced by the studied drying off period before harvesting, in the two seasons. The highest sugar yield was obtained from sugar cane dried-off for 30 days before harvesting, which out-yielded that fastened for 15, 45 and 60 days by $0.231,0.201$ and 0.592 ton of sugar/fad, in the $1^{\text {st }}$ season, 
corresponding to $0.259,0.180$ and $0.492 \mathrm{ton} / \mathrm{fad}$, in the $2^{\text {nd }}$ one, successively. These results can be referred to the main components of the sugar yield i.e., sugar recovery \% (Table 6) and cane yield/fed (Table 7), where sugar recovery $\%$ had the same trend as affected by irrigation withholding period. Although, the highest cane yield/fed was obtained by canes fastened for 15 days before harvesting, insignificant variance was detected with that dried-off for 30 days, showing the important and distinct influence of sugar recovery $\%$ on the extracted sugar yield/fad. These results are in agreement with these obtained by Khaleifah (1990); Abdelkarim and Mahdi (2015); Getaneh, et al. (2015); Araújo, et al. (2016) and Ashagre and Khan (2020), who found that withholding irrigation before harvest, have a significant effect on sugar yield.

Table (8): Effect of drying-off period on sugar yield/fad (ton) of some sugar cane varieties in the plant and first ratoon crops, during 2018/2019 and 2019/2020

\begin{tabular}{|c|c|c|c|c|c|c|c|c|c|c|}
\hline \multirow{3}{*}{$\begin{array}{c}\text { Sugarcane } \\
\text { Varieties }\end{array}$} & \multicolumn{5}{|c|}{ Plant cane crop } & \multicolumn{5}{|c|}{$1^{\text {st }}$ ratoon crop } \\
\hline & \multicolumn{4}{|c|}{ Drying-off period (day) } & \multirow{2}{*}{ Mean } & \multicolumn{4}{|c|}{ Drying-off period (day) } & \multirow{2}{*}{ Mean } \\
\hline & 15 & 30 & 45 & 60 & & 15 & 30 & 45 & 60 & \\
\hline G.T.54-9 & 5.867 & 6.166 & 6.024 & 5.563 & 5.905 & 5.557 & 5.860 & 5.757 & 5.360 & 5.634 \\
\hline G.84-47 & 5.461 & 5.691 & 5.584 & 5.236 & 5.493 & 5.424 & 5.703 & 5.670 & 5.376 & 5.543 \\
\hline G.2003-47 & 6.094 & 6.398 & 6.117 & 5.792 & 6.100 & 5.910 & 6.207 & 5.953 & 5.710 & 5.945 \\
\hline G.99-103 & 6.003 & 6.188 & 5.916 & 5.417 & 5.881 & 5.847 & 6.075 & 5.806 & 5.396 & 5.781 \\
\hline Cu. 57-14 & 5.352 & 5.485 & 5.285 & 4.962 & 5.271 & 5.286 & 5.475 & 5.235 & 5.016 & 5.253 \\
\hline Mean & 5.755 & 5.986 & 5.785 & 5.394 & & 5.605 & 5.864 & 5.684 & 5.372 & \\
\hline \multicolumn{11}{|c|}{ LSD at 0.05 level for: } \\
\hline \multirow{2}{*}{\multicolumn{5}{|c|}{ Drying-off periods (A) }} & \multicolumn{5}{|l|}{0.200} & 0.162 \\
\hline & & & & & 0.210 & & & & & 0.162 \\
\hline \multicolumn{5}{|c|}{ A $\times$ B } & \multicolumn{5}{|l|}{0.421} & 0.324 \\
\hline
\end{tabular}

Data in the same table disclose that sugarcane varieties varied significantly in sugar yield in both seasons. Sugarcane G.2003-47 variety recorded the highest value of this trait in the plant cane crop without statistical variance with that recorded by G.T.54-9, in the $1^{\text {st }}$ season. Meanwhile, G.2003-47 grown as a plant cane crop recorded 0.195, 0.607, 0.219 and 0.829 ton of sugar higher than that given by G.T.54-9, G.84-47, G.99-103 and C.57-14, respectively, in the first ratoon crop. Likewise, it produced $0.311,0.402$. 0.164 and 0.692 ton, successively as compared with the same varieties, grown as first ratoon cane crop. The superiority of G.2003-47 cane variety can be attributed to the highest and distinguished value of sugar recover\% recorded by this variety, in comparison to the other tested ones (Table 6). The variability among the evaluated cane varieties was also reported by El-Geddawy, et. al. (2002); El-Shafai and Ismail (2006); Abazied (2018) and Gadallah and Mehareb (2020).

Sugar yield, extracted from the plant cane or $1^{\text {st }}$ ratoon crop was markedly affected by the interaction between the two studied factors. Significant reduction was recorded in sugar yield gained from G.T.54-9 
and G.99-103 varieties, when fasting period was prolonged for 45 to 60 days before harvesting, without significant variance between these irrigations cutting-off periods in their effect on sugar yield produced by the other tested varieties, in plant and ratoon cane crops. Generally, the highest sugar yield (6.398 and 6.207) was recorded by harvesting G. 2003-47 after 30 days drying-off. In $1^{\text {st }}$ and $2^{\text {nd }}$ seasons, respectively.

\section{CONCLUSION}

Drying-off of sugarcane crop after attaining full growth has led to an improvement in its quality traits and sugar yields, while cane and sugar yields are negatively affected by extending fasting period.

Under the conditions of the present work, on Kom Ombo region, irrigation of sugarcane crop should be withheld for 30 days before harvesting in in March to obtain maximum sugar yield per faddan. Further study is required to find out the appropriate fasting period preceding later harvesting of sugarcane.

\section{REFERENCES}

Abazied, Sakina R. (2018): Influence of delivery delay on quality of some promising sugar cane varieties under Aswan condition. Proc. $15^{\text {th }}$ Agron. Conf. Crop Sci., Ain Shams Univ., Cairo, Egypt pp. 21-29.

Abdelkarim, D.E. and K.M. Mahdi (2015): Effect of dry-off period and crushing and extracting delays on sugarcane quality and productivity. Transact. Ind., Financ. \& Bus. (IFBM), 3 (5): 67-72.

Abiy, G. and T. Negi (2014): Effect of length of pre-harvest drying-off period during the cool season on soil moisture content and cane quality of sugarcane cultivars at Metahara Sugar Estate. Afr. J. Agro., 2 (9): 211-218.

Ahamed, A.Z.; E.H.S. El-Laboudy and Sherin H.A. Al-Maracy (2020): Productivity and quality of some sugar cane varieties as influenced by seeding rate. J. Biol., Chem. Environ., Sci., 15 (2): 31-47.

Araújo, R.; J.A.J.D. Casaroli and A.W. P. Evangelista(2016): Variation in the sugar yield in response to drying-off of sugarcane before harvest and the occurrence of low air temperatures. Bragantia J., 75 (1):118-127.

Ashagre, S. Y. and A.Q. Khan (2020): Determining optimum period of withholding irrigation for inducing maturity of sugarcane (Saccharum spp. hybrid) in Southern Ethiopia. J Appl. Biotechnol, Bioeng, 7 (2):16-25. 
A.O.A C (2005): Association of Official Agricultural Chemists "Official Methods of Analysis", published by the A.O.A.C., Box 540, Washington. D.C.

Donaldson, R. A. and C. N. Bezuidenhout (2000): Determining the maximum drying-off periods for sugar cane grown in different regions of the south African industry. Proc. S Afr. Sug. Technol. Ass., 74: 162-166.

El-Geddawy, I.H.; D.G. Darweish; A.A. El-Sherbiny and E.E.A. ElHady (2002): Effect of row spacing and number of bud/seed setts on: 2. Juice quality of ratoon crop for some sugar cane varieties. Pakistan Sugar J., 17 (4): 10-17.

EL-Maghraby, Samia S. ; A.Z. Ahmed and K.S. EL-Soghier (2009): Post-harvest change studies in sugar cane cultivars under upper Egypt condition. Proc. $9^{\text {th }}$ African Crop Science Cape Town south Africa. Pp 31-37.

El-Shafai, A. M. A. and A. M. A. Ismail (2006): Effect of row spacing on yield and quality of some promising sugarcane varieties. Egypt J. Appl. Sci. 21 (11), 32-46.

E.S.I.I.C. (1981): Egyptian Sugar and Integrated Industries Company "Chemical control Lab". Jan., p.232.

Gadallah, A.F.I. and E.M. Mehareb (2020): Yield and quality of some sugarcane varieties as affected by irrigation number. Nter. J. Agric. Sci., 2 (2): 144-165.

Getaneh, A. and T. Negi ( 2014): Effect of length of pre-harvest drying-off period during the cool season on soil moisture content and cane quality of sugarcane cultivars at Metahara Sugar Estate. African J. Agro., 2 (9): 211-218.

Getaneh, A. ; T. Negi ; N. Ayele and Z. Teshome (2015): Study on Dry-off period before harvest at Finchaa Sugarcane Plantation: Cool Season Study. J. Agric., Natu., Res., Sci., 2(1): 281-28

Hagos, H. ; W. Worku and A. Takele (2014): Effect of drying off period and harvest age on quality and yield of ratoon cane (Saccharium officinarium L.). Adv. Crop Sci., Tech. 2: 133-137.

Hebert, L. P. (1973): Testing of sugarcane varieties for milling quality. The Sugar J. 36 (4): 8-12.

Inman-Bamber, N.G. and D.M. Smith (2005): Water relations in sugarcane and response to water deficits. Field Crops Res., 92: 185-202. 
Khaleifah, M.A. (1990): Studies on cane sugar technology. Ph.D. Thesis, Fac. Agric., El-Minia Univ., El- Minia, Egypt.

Mathur, R.B.L. (1997): Handbook of cane technology. Oxford IBH publishing Co.

Olivier; F.C. ; R.A. Donaldson, and A. Singels (2006): Drying off sugarcane on soils with low water holding capacity. Proc., South African Sugar Cane Techno., Ass.; 80: 183-187.

Singh, R. P. and P. P. Singh (1998): Quality of juice and commercial sugar cane as influenced by crop cane. Indian J. Sugar, 48 (1):21-28.

Snedecor, G. W. and W. G. Cochran (1981): Statistical Methods. Seventh Ed., Iowa State Univ. Press, Ames, Iowa, USA.

Steel, R. G. D. and J. H. Torrie (1980): Principles and procedures of statistics. Mc Grow-Hill Book Co. Inc., New York.

Taha, E. M.; Sh.A. Mokadem; A. Z. Ahmed and M.O. Galal (2008): Assessment of the optimum seeding rate and nitrogen level for five sugarcane varieties. Minia J. Agric. Res. \& Develop, 28 (3): $469-494$.

Yadav, R.L. and R. K. Sharma (1980): Effect of nitrogen level and harvesting date on quality characteristics and yield of four sugar cane genotypes. Indian J. Agric. Sci., 50: 581-589.

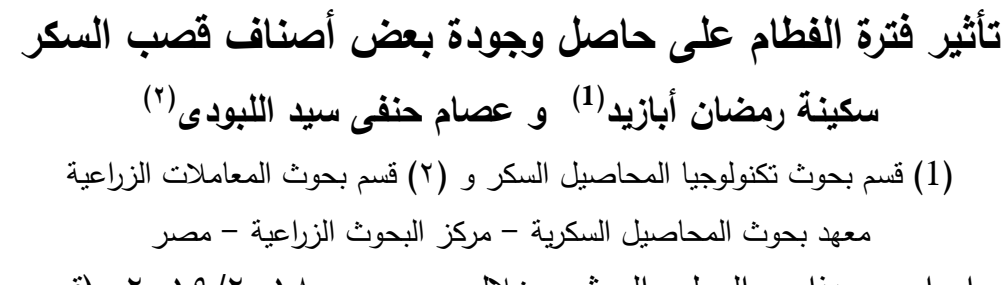

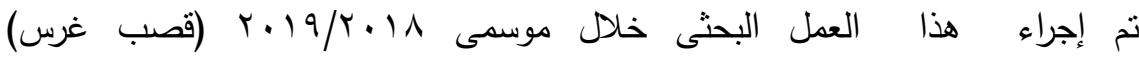

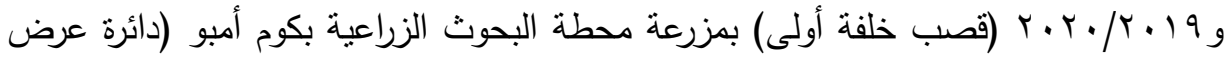

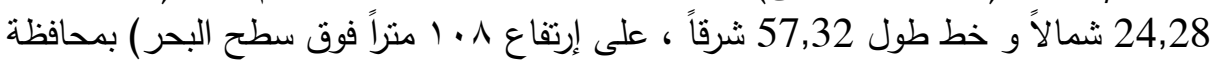

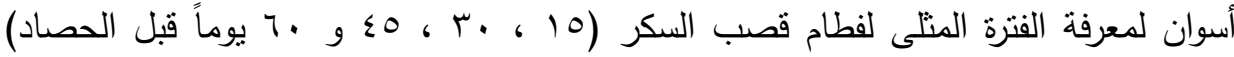

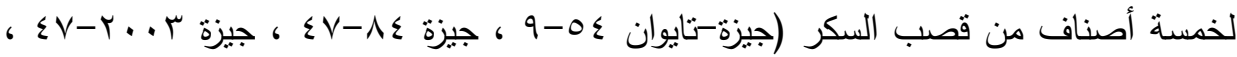

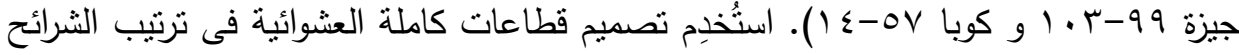

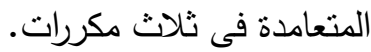

أظهرت النتائج أن جميع الصفات فات محل الدراسة قد ثأثرت معنوياً بفترة الفطام قبل

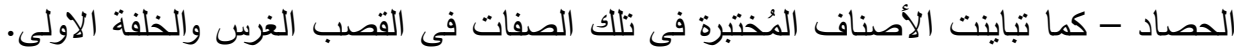

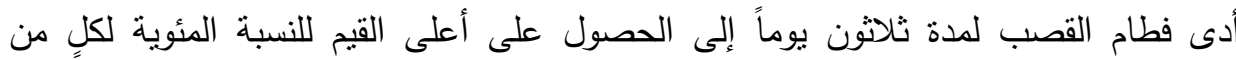

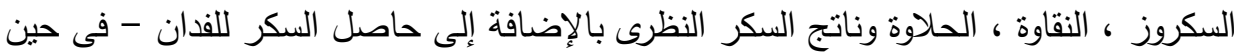


تم التحصل على أعلى قيم لوزن العيدان القابلة للعصر وحاصل القصب للفدان بفطام القصب لمدة خمسة عشر بوماً.

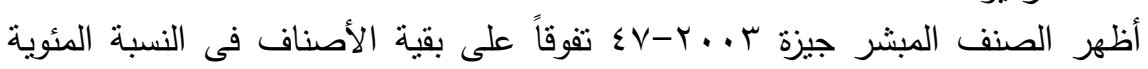

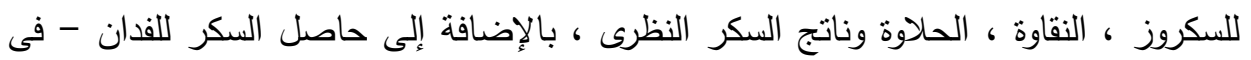

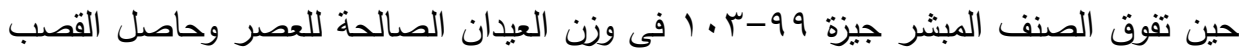
النظيف للفدان.

تحت ظروف منطقة كوم امبو ، يمكن التوصية بمنع رى (فطام) القصب لمدة ثلاثثين يوماً قبل الحصاد فى شهر مارس. 